\title{
Synthesis and Antimicrobial and Antioxidant Activities of Some New 5-(2-Methyl-1H-indol-3-yl)-1,3,4-oxadiazol- 2-amine Derivatives
}

\author{
Anand R. Saundane, ${ }^{1}$ Vaijinath A. Verma, ${ }^{2}$ and Vijaykumar T. Katkar ${ }^{1}$ \\ ${ }^{1}$ Department of Post-Graduate Studies and Research in Chemistry, Gulbarga University, Gulbarga 585 106, India \\ ${ }^{2}$ Shri Prabhu Arts, Science \& J. M. Bohra Commerce Degree College, Shorapur, Karnataka 585 224, India \\ Correspondence should be addressed to Anand R. Saundane; arsaundane@rediff.com
}

Received 31 May 2013; Revised 18 August 2013; Accepted 9 September 2013

Academic Editor: Jose Alberto Pereira

Copyright (c) 2013 Anand R. Saundane et al. This is an open access article distributed under the Creative Commons Attribution License, which permits unrestricted use, distribution, and reproduction in any medium, provided the original work is properly cited.

\begin{abstract}
A series of 5-(2-methyl-1H-indol-3-yl)-1,3,4-oxadiazol-2-amine derivatives (3-5) were synthesized. These previously unknown compounds were characterized by spectral studies and elemental analysis. These compounds were evaluated for their antimicrobial and antioxidant activities. Among all the compounds tested 5d exhibited promising antibacterial, antifungal, radical scavenging, and ferric ions $\left(\mathrm{Fe}^{3+}\right)$ reducing antioxidant power (FRAP) activities, whereas the compounds $\mathbf{3 b}$, $\mathbf{4} \mathbf{c}$, and $\mathbf{5 e}$ exhibited good FRAP and metal chelating activities. In general compounds containing chloro and methyl substituent exhibited better antimicrobial and antioxidant activities.
\end{abstract}

\section{Introduction}

Indole and its analogs display remarkable pharmacological activities like Hepatitis C Virus NS5B protein inhibitiors [1-3] peroxisome proliferator-activated receptor $\gamma$ (PPAR- $\gamma$ ) agonist [4], antiproliferative against human tumor cells $[5,6]$, antibacterial, antifungal [7, 8], and anticoccidal [9] activities. On the other hand, oxadiazoles possess desirable electronic and charge transport properties into which various functional groups can be easily introduced. Considerable evidence has been accumulated during the last decades demonstrating the various pharmacological properties of its isomer 1,3,4oxadiazole which includes anticonvulsant [10], tuberculostic [11], analgesic and ulcerogenicity [12], antibacterial, antifungal, diuretic [13], antimiotic [14], anti-inflammatory [15], antiHIV [16], nonpeptide angiotensin II receptor antagonists [17], tyrosinase inhibition [18], nematocidal, insecticidal, and herbicidal [19] activities. All of which can be attributed to its characteristic properties of electrophilic substitution, and nucleophilic substitution, thermal and photochemical reactions due to the presence of $-\mathrm{N}=\mathrm{C}-\mathrm{O}$ - group. The importance of substituted indolyloxadiazoles is well known for various applications. Indolyl-1,3,4-oxadiazoles, triazoles, and pyrazoles have been reported as antimicrobials $[20,21]$.
Indole substituted with oxadiazoles or triazoles at positions 1 and/or 3 were found to exhibit enhanced biological activities [22]. In the perspective of bioactivities of the abovementioned structures and in search of novel antimicrobials and antioxidants, we herein report synthesis of novel bis (indolyl) analogues.

\section{Results and Discussion}

The synthetic strategy was planned as depicted in Scheme 1. The requisite starting materials 5-(2-methyl- $1 H$-indol-3-yl)1,3,4-oxadiazol-2-amine (1) were prepared by the cyclocondensation of 2-methyl- $1 \mathrm{H}$-indol-3-carbohydrazide with cyanogen bromide in ethanol under reflux conditions [23] and 5-substituted 2-phenyl- $1 \mathrm{H}$-indol-3-carboxaldehydes $\mathbf{2 a -}$ c were prepared by the previously reported method [24]. Condensation of compound $\mathbf{1}$ with $\mathbf{2 a - c}$ in methanol, under reflux temperature afforded the key intermediate $\mathrm{N}$-[(5-substituted 2-phenyl-1H-indol-3-yl) methylene]-5-(2methyl-1H-indol-3-yl)-1,3,4-oxadiazol-2-amines (3a-c).

Compounds $3 \mathbf{a}-\mathbf{c}$ on cyclocondensation with easily available and economically viable reagents such as thioglycolic acid, phenyl acetyl chloride, and chloro acetyl chloride 


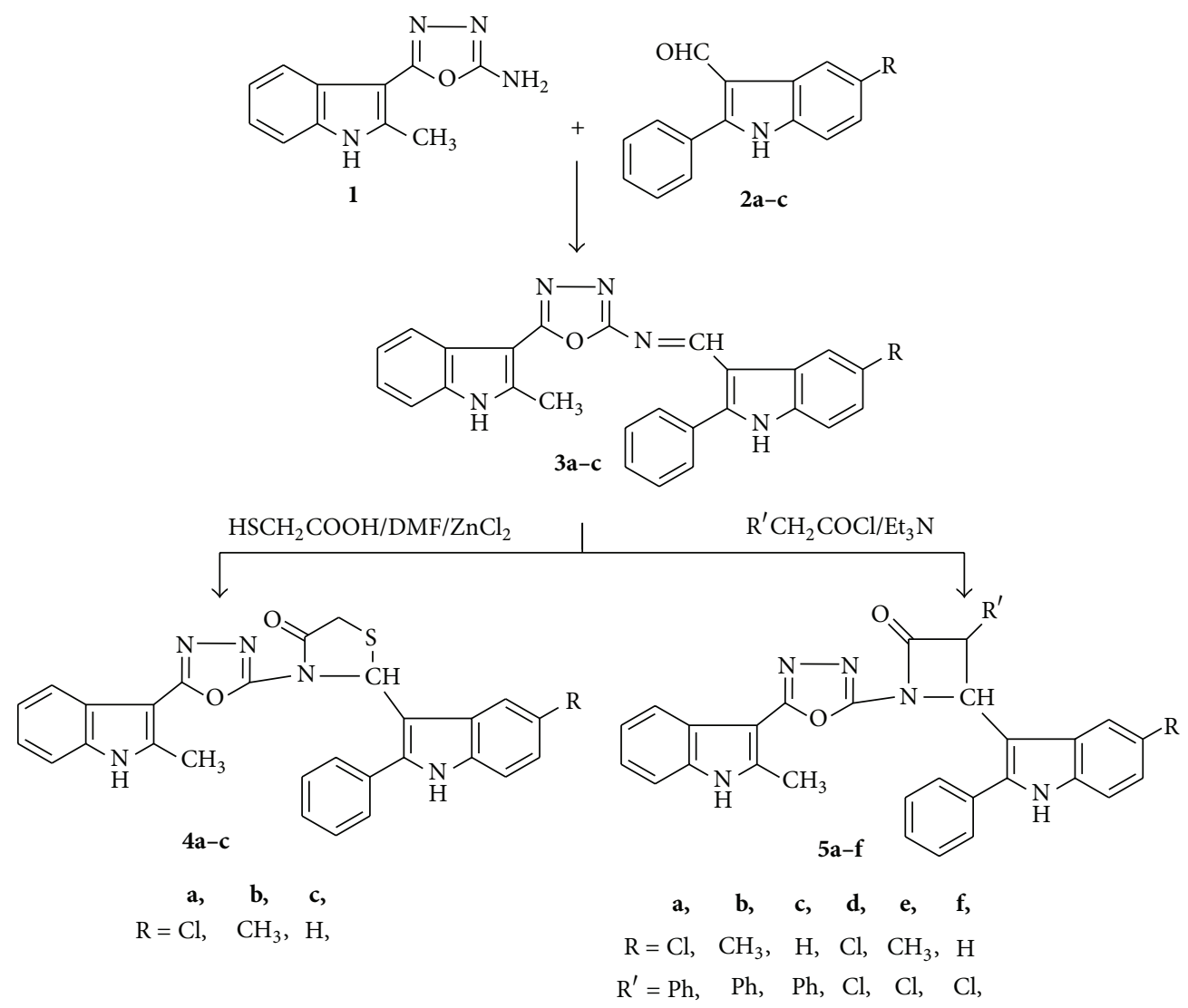

SCHEME 1: Schematic pathway for the synthesis of title compounds.

yielded 2-(5-substituted 2-phenyl-1H-indol-3-yl)-3-[5-(2methyl-1H-indol-3-yl)-1,3,4-oxadiazol-2-yl] thiazolidin-4ones (4a-c), 4-(5-substituted 2-phenyl-1H-indol-3-yl)-1-[5(2-methyl-1H-indol-3-yl)-1,3,4-oxadiazol-2-yl]-3-phenylazetidin-2-ones $(\mathbf{5 a}-\mathbf{c})$, and 3-chloro-4-(5-substituted 2-phenyl-1H-indol-3-yl)-1-[5-(2-methyl- $H$-indol-3-yl)-1,3,4-oxadiazol-2-yl]azetidin-2-ones (5d-f), respectively.

2.1. Antimicrobial Activities. Antimicrobial screening of the compounds (1 and 3-5) was performed by cup-plate method at a concentration of $1 \mathrm{mg} / \mathrm{mL}$ following reported procedure [25]. The bacteria Escherichia coli, Bacillus subtilis, and Klebsiella pneumonia and fungal Aspergillus niger, Aspergillus flavus, and Aspergillus fumigates were used. The zones of inhibition were compared with the standards; streptomycin and fluconazole were used as standards for antibacterial and antifungal activities, respectively. The results are presented in Table 1.

The structure-activity relationship (SAR) revealed that the compounds with chlorine substituent at C-5 position of indole and in azetidinone system are important for enhancing the antimicrobial activity, whereas methyl substituent at C5 position of indole is found to reduce the antimicrobial activity. Thus, compound $\mathbf{5 d}$ has been found to exhibit maximum zone of inhibition against all the bacteria and fungi. Replacement of azetidinone nucleus by thiazolidinone system leads to formation of compounds $\mathbf{4 a - c}$ with decreased antimicrobial activity. On the other hand, compounds 3 a and $\mathbf{4 a}$ exhibited less zone of inhibition compared to $\mathbf{5 d}$ against all bacterial strains and the fungus $A$. niger. Removal of chlorine substituent at C-5 position of indole (compound 5f) leads to decrease in antibacterial activity against $B$. subtilis. Replacement of chlorine at C-5 position of indole by methyl group and azetidine system by thiazolidinone ring (compound $4 \mathbf{b}$ ) exhibited same zone of inhibition as that of $\mathbf{5 d}$ against bacterial strain K. pneumonia and showed slight decrease in antifungal activity against $A$. flavus. Substitution of chlorine by phenyl group in $\mathbf{5 d}$ (compound 5 a) leads to decrease in antifungal activity against $A$. flavus and A. fumigates. On the same line, when chlorine at C5 position of indole in $\mathbf{5} \mathbf{d}$ was replaced by methyl group (compound $\mathbf{5 e}$ ) slight decrease in antifungal activity against A. fumigates was noticed. However, none of the compounds exhibited better antimicrobial activity compared with standards.

\subsection{Antioxidant Activities}

2.2.1.1,1-Diphenyl-2-picryl Hydrazyl (DPPH) Radical Scavenging Activity (RSA). Investigation of the RSA of the test compounds (1 and $\mathbf{3}-\mathbf{5}$ ) was conducted as described by Hatano's and colleagues [26] and the results were compared with the 
TABLE 1: Antimicrobial activities of the compounds (1 and 3-5).

\begin{tabular}{|c|c|c|c|c|c|c|c|c|}
\hline \multirow{3}{*}{ Compound no. } & \multirow{3}{*}{$\mathrm{R}$} & \multirow{3}{*}{$\mathrm{R}^{\prime}$} & \multicolumn{6}{|c|}{ Diameter of zone of inhibition in $\mathrm{mm}^{\#}$} \\
\hline & & & \multicolumn{3}{|c|}{ Antibacterial activity } & \multicolumn{3}{|c|}{ Antifungal activity } \\
\hline & & & E. coli & B. subtilis & K. pneumonia & A. niger & A. flavus & A. fumigates \\
\hline 1 & - & - & $14 \pm 1.63$ & $12 \pm 1.31$ & $14 \pm 1.88$ & $17 \pm 1.60$ & $14 \pm 1.76$ & $11 \pm 1.81$ \\
\hline $3 a$ & $\mathrm{Cl}$ & - & $10 \pm 2.29$ & $14 \pm 1.27$ & $06 \pm 1.93$ & $09 \pm 1.41$ & $12 \pm 1.06$ & $13 \pm 1.68$ \\
\hline $3 b$ & $\mathrm{CH}_{3}$ & - & $05 \pm 1.83$ & $09 \pm 1.25$ & $13 \pm 1.85$ & $08 \pm 0.67$ & $11 \pm 1.60$ & $18 \pm 1.43$ \\
\hline $3 c$ & $\mathrm{H}$ & - & $02 \pm 1.01$ & $07 \pm 1.06$ & $12 \pm 1.35$ & $00 \pm 0.00$ & $05 \pm 1.35$ & $03 \pm 1.81$ \\
\hline $4 a$ & $\mathrm{Cl}$ & - & $14 \pm 2.00$ & $14 \pm 1.72$ & $10 \pm 2.80$ & $18 \pm 1.82$ & $13 \pm 1.82$ & $08 \pm 2.00$ \\
\hline $4 b$ & $\mathrm{CH}_{3}$ & - & $06 \pm 1.43$ & $03 \pm 1.39$ & $15 \pm 2.25$ & $08 \pm 1.96$ & $19 \pm 2.16$ & $07 \pm 1.76$ \\
\hline $4 c$ & $\mathrm{H}$ & - & $10 \pm 2.05$ & $09 \pm 1.02$ & $07 \pm 1.54$ & $06 \pm 1.49$ & $04 \pm 1.47$ & $09 \pm 1.76$ \\
\hline $5 a$ & $\mathrm{Cl}$ & $\mathrm{Ph}$ & $03 \pm 1.57$ & $14 \pm 1.73$ & $04 \pm 1.51$ & $12 \pm 1.88$ & $19 \pm 0.94$ & $17 \pm 1.72$ \\
\hline $5 b$ & $\mathrm{CH}_{3}$ & $\mathrm{Ph}$ & $13 \pm 2.15$ & $10 \pm 1.56$ & $05 \pm 1.61$ & $05 \pm 1.39$ & $01 \pm 0.76$ & $13 \pm 1.68$ \\
\hline $5 c$ & $\mathrm{H}$ & $\mathrm{Ph}$ & $07 \pm 1.24$ & $11 \pm 1.49$ & $12 \pm 1.96$ & $9 \pm 1.92$ & $14 \pm 1.48$ & $12 \pm 0.91$ \\
\hline $5 d$ & $\mathrm{Cl}$ & $\mathrm{Cl}$ & $16 \pm 2.23$ & $15 \pm 2.16$ & $15 \pm 1.96$ & $19 \pm 1.72$ & $20 \pm 1.68$ & $18 \pm 1.49$ \\
\hline $5 e$ & $\mathrm{CH}_{3}$ & $\mathrm{Cl}$ & $02 \pm 1.23$ & $08 \pm 1.15$ & $05 \pm 1.48$ & $07 \pm 1.72$ & $05 \pm 1.68$ & $17 \pm 1.50$ \\
\hline $5 f$ & $\mathrm{H}$ & $\mathrm{Cl}$ & $10 \pm 1.60$ & $14 \pm 1.35$ & $07 \pm 1.28$ & $12 \pm 0.95$ & $15 \pm 1.12$ & $08 \pm 1.39$ \\
\hline Std-1 & - & - & $17 \pm 1.80$ & $16 \pm 1.92$ & $16 \pm 2.29$ & - & - & - \\
\hline Std-2 & - & - & - & - & - & $20 \pm 1.61$ & $22 \pm 1.61$ & $19 \pm 1.81$ \\
\hline
\end{tabular}

Including diameter of well ${ }^{\#}$, control $(\mathrm{DMF})=$ no activity, Std-1 = streptomycin, Std-2 = fluconazole.

results obtained using standards 2-tert-butyl-4-methoxy phenol (butylated hydroxyl anisole, BHA), 2-(1,1-dimethylethyl)1,4-benzenediol (tertiary butylated hydroquinone, TBHQ), and ascorbic acid (AA).

From the RSA results of test compounds (Figures 1 and 2) it could be seen that introduction of chlorine substitution at $\mathrm{C}-5$ position of indole ring (compound $\mathbf{3 a}$ ) enhances the RSA $(72.35 \%$ at $100 \mu \mathrm{g} / \mathrm{mL})$, whereas the introduction of methyl group at same position of indole (compound $3 \mathbf{b}$ ) leads to decrease in RSA $(55.28 \%$ at $100 \mu \mathrm{g} / \mathrm{mL})$. Replacement of the azomethine group in compounds 3 by thiazolidinone nucleus (compounds 4) resulted in a decrease in RSA. But replacement of azomethine group by azetidinone ring with the chlorine substitution at $\mathrm{C}-5$ of indole (compound 5d) was found to enhance the RSA $(74.15 \%$ at $100 \mu \mathrm{g} / \mathrm{mL})$. Replacement of chlorine substituent by phenyl group in azetidinone system (compound 5a) or replacement of chlorine substitution by phenyl group in azetidinone ring and methyl group at $\mathrm{C}-5$ position of indole (compound $\mathbf{5 b}$ ) was found to decrease RSA $(62.12 \%$ at $100 \mu \mathrm{g} / \mathrm{mL})$.

\subsubsection{Ferric Ions $\left(\mathrm{Fe}^{3+}\right)$ Reducing Antioxidant Power (FRAP).} The ferric ion $\left(\mathrm{Fe}^{3+}\right)$ is a relatively biologically inactive form of iron. However, it can be reduced to active $\mathrm{Fe}^{2+}$, depending on the condition, particularly $\mathrm{pH}$ [27] and oxidized back through Fenton type reaction with production of hydroxyl radical or Haber-Weiss reaction with the generation of superoxide anions. Reducing power is to measure the reductive ability of antioxidant. It is evaluated by the transformation of $\mathrm{Fe}^{3+}$ to $\mathrm{Fe}^{2+}$ by donation of an electron, in the presence of test compounds. Therefore, the $\mathrm{Fe}^{2+}$ can be monitored by measuring the formation of Perl's Prussian blue at $700 \mathrm{~nm}$.

Determination of the reducing power of the compounds (1 and 3-5) at different concentrations $(25,50,75$, and

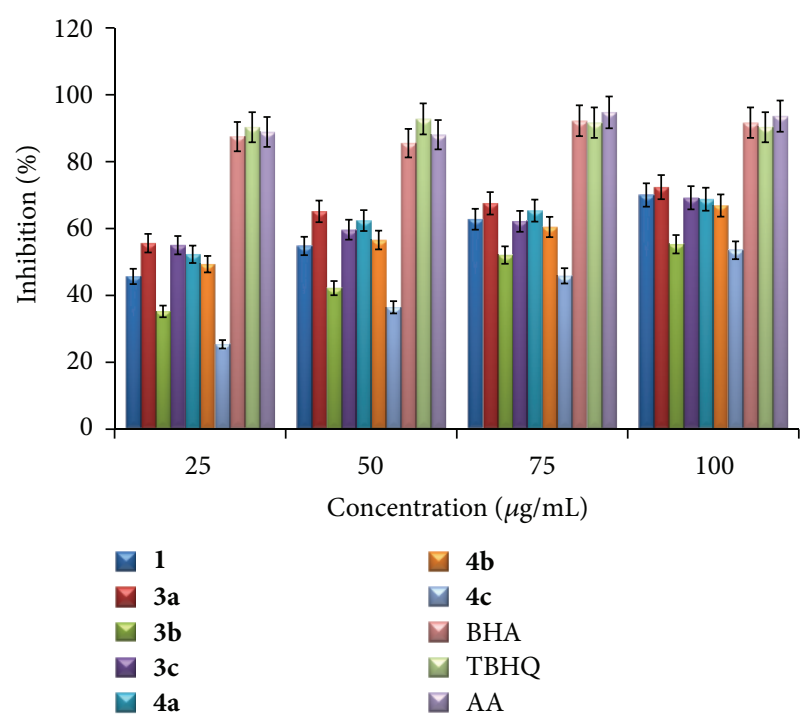

Figure 1: RSA of the compounds (1 and 3-4).

$100 \mu \mathrm{g} / \mathrm{mL}$ ) was conducted by Oyaizu method [28] using BHA, TBHQ, and AA as standards. The FRAP results (Figures 3 and 4) revealed that methyl substitution at C-5 position of indole (compound $\mathbf{3 b}$ ) leads to increase in FRAP, whereas introduction of chlorine substituent at C-5 of indole (compound 3d) leads to decrease in FRAP. Replacement of azomethine group by thiazolidinone ring (compound 4a) increases the FRAP, but introduction of either chlorine or methyl substituent (compound $\mathbf{4 a}$ and $\mathbf{4 b}$ ) leads to decrease in FRAP, whereas replacement of azomethine group by azetidinone ring with chloro substitution (compound 5e) exhibited promising FRAP. Introduction of chlorine or 


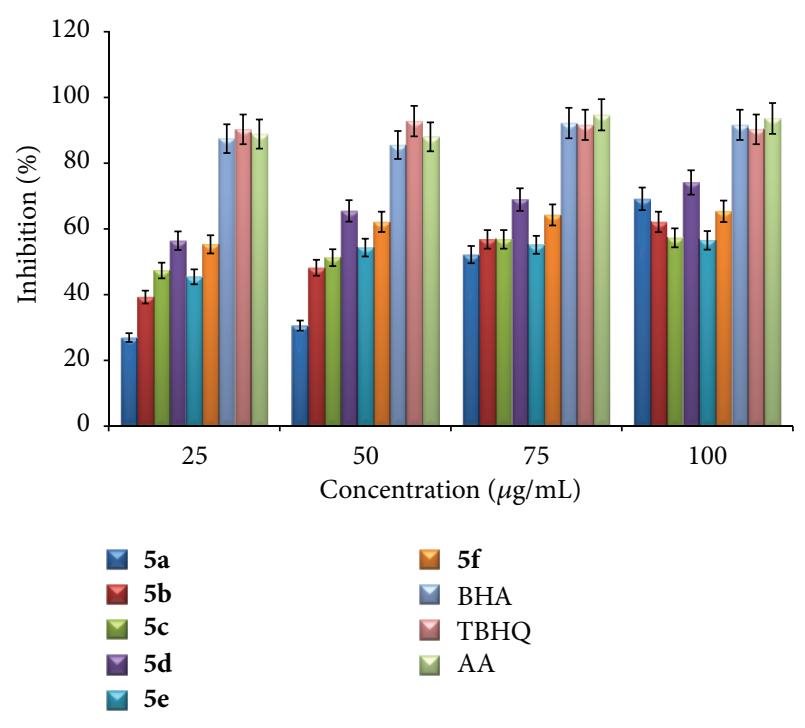

Figure 2: RSA of the compounds (5a-f).

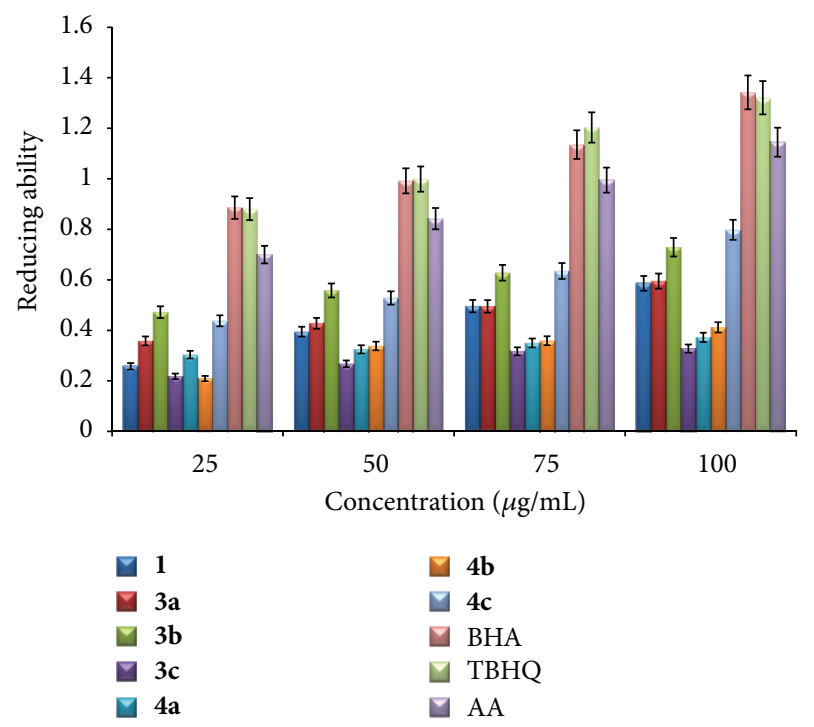

Figure 3: Ferric $\left(\mathrm{Fe}^{3+}\right)$ ions reducing capacity of the compounds (1 and 3-4).

methyl substituent at C-5 position of indole and replacement of chlorine by phenyl group in azetidinone ring (compounds $\mathbf{5 a}$ and $\mathbf{5 b})$ lead to decrease in FRAP.

2.2.3. Ferrous $\left(\mathrm{Fe}^{2+}\right)$ Metal Ion Chelating Activity. The chelating effect of ferrous ions $\left(\mathrm{Fe}^{2+}\right)$ towards the test compounds ( 1 and 3-5) and standards were determined by following Dinis method [29] and the results were compared with standards BHA, TBHQ, and AA. Ferrozine can make complexes with ferrous ions. In the presence of chelating agents, complex (red colored) formation is interrupted, as a result the red color of the complex is decreased. Thus, the chelating effect of the coexisting chelator can be determined by measuring the rate of color reduction.

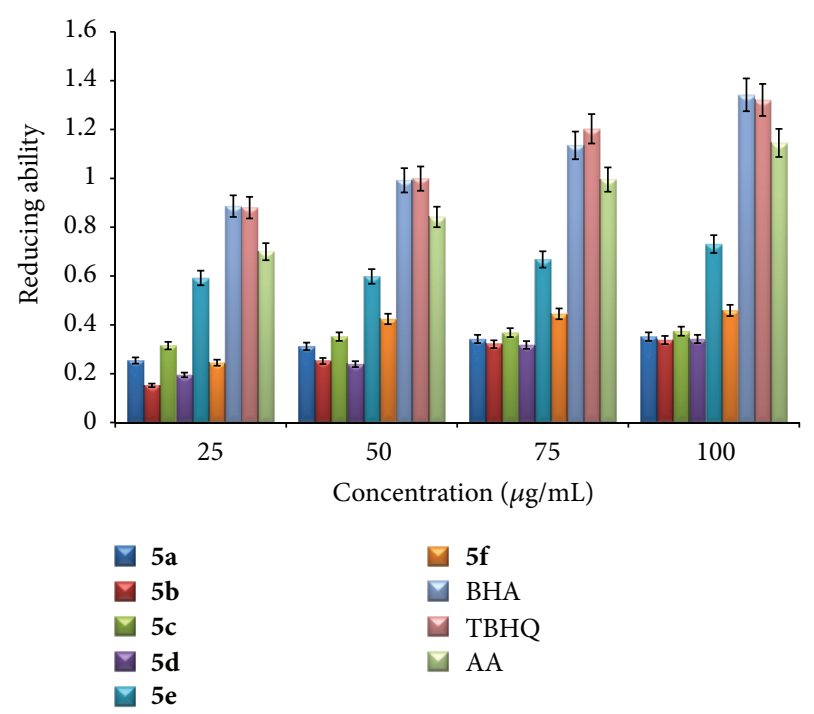

Figure 4: Ferric $\left(\mathrm{Fe}^{3+}\right)$ ions reducing capacity of the compounds $(5 \mathbf{a}-\mathbf{f})$.

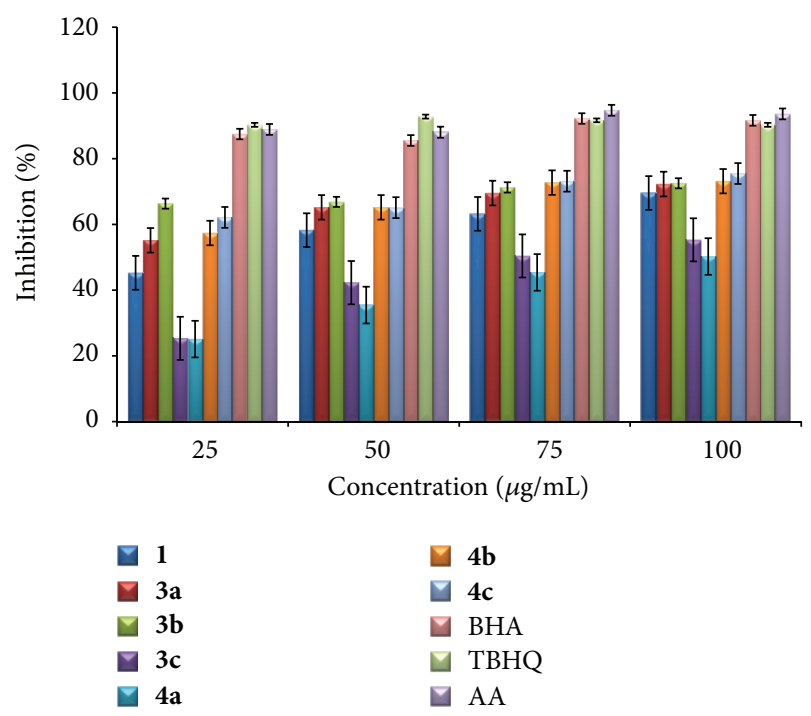

FIGURE 5: Metal chelating activity of the compounds (1 and 3-4).

In metal chelating activity (Figures 5 and 6), the SAR study revealed that introduction of chloro or methyl substitution at C-5 position of indole (compounds $\mathbf{3} \mathbf{a}$ and $\mathbf{3 b}$ ) along with azomethine group leads to improved metal chelating activity ( 71.24 and $72.51 \%$ at $100 \mu \mathrm{g} / \mathrm{mL}$, resp.). Replacement of azomethine group by thiazolidinone ring (compound $4 \mathrm{c}$ ) showed higher activity $(75.48 \%$ at $100 \mu \mathrm{g} / \mathrm{mL})$. Introduction of methyl group (compound $\mathbf{4 b}$ ) leads to slight decrease in metal chelating activity, whereas introduction of chlorine at C-5 position of indole (compound 4a) drastically reduced the metal chelating activity. Introduction of chlorine substituent at C-5 position of indole (compound 5d) was found to increase metal chelating activity $(66.25 \%$ at $75 \mu \mathrm{g} / \mathrm{mL})$, whereas the introduction of either chloro or methyl substituent at C-5 position of indole and phenyl substitution in 


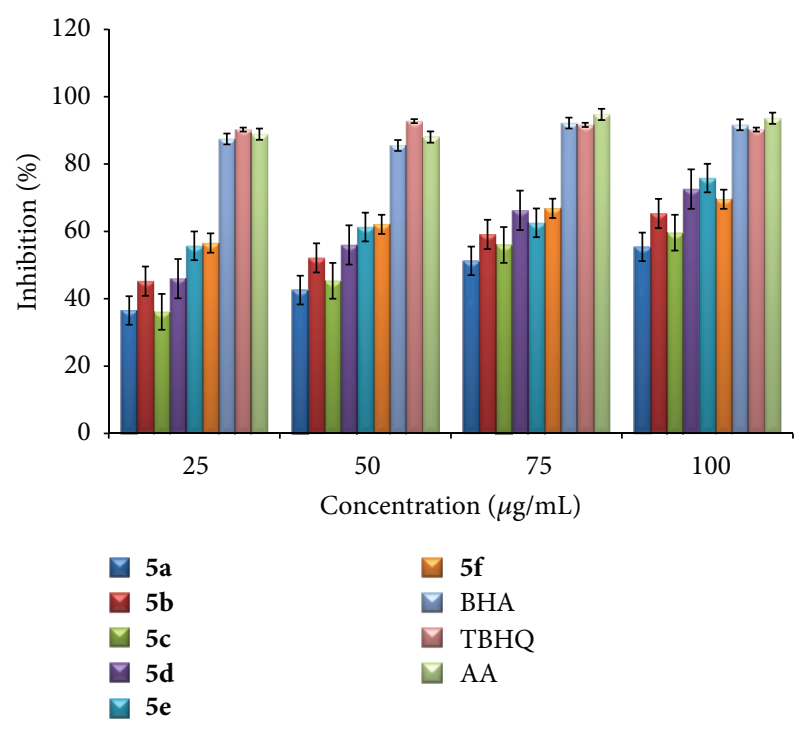

FIGURE 6: Metal chelating activity of compounds (5a-f).

azetidinone ring (compound $\mathbf{5 a}$ and $\mathbf{5 b}$ ) lead to decrease in metal chelating activity. Replacement of azomethine group by azetidine ring with methyl substituent at C-5 position of indole and chloro substitution in azetidinone ring (compound 5e) exhibited higher metal chelating activity $(75.84 \%$ at $100 \mu \mathrm{g} / \mathrm{mL}$ ). However, none of the compounds showed activity better than the standards.

\section{Conclusion}

We have reported the synthesis and antimicrobial and antioxidant activities of novel bis (indolyl) compounds 1, 3ac, $4 \mathbf{a}-\mathbf{c}$, and $\mathbf{5 a - f}$. Compounds bearing chloro substitution exhibited significant antimicrobial and antioxidant activities. Among the synthesized compounds, $\mathbf{5 d}$ was found to be most active against all the microorganism tested and also exhibited promising RSA and FRAP suggesting that the presence of chloro substituent and the azetidinone nucleus are responsible for activities among the synthesized compounds.

\section{Experimental Protocol}

All the chemicals and reagents were commercially obtained and used by further purification. Melting points were determined by an open capillary method and are uncorrected. Purity of the compounds was checked by TLC using silica gelG coated aluminium plates (Merck) and spots were visualized by exposing the dry plates in iodine vapours. The IR ( $\mathrm{KBr})$ spectra were recorded with a Perkin-Elmer spectrum one FT-IR spectrometer. The ${ }^{1} \mathrm{H}$ NMR $\left(\mathrm{DMSO}-d_{6}\right)$ spectra were acquired with a Bruker NMR $(500 \mathrm{MHz})$ and the chemical shifts are expressed in ppm ( $\delta$ scale) downfield from TMS. Mass spectra were obtained with a JEOL GCMATE II GC-MS mass spectrometer. Elemental analysis was carried out using Flash EA 1112 series elemental analyzer.
4.1. General Procedure for the Synthesis of 5-(2-Methyl1H-indol-3-yl)-1,3,4-oxadiazol-2-amine (1). A mixture of 2methyl- $1 H$-indol-3-carbohydrazide $(0.01 \mathrm{~mol})$ and cyanogen bromide $(0.01 \mathrm{~mol})$ in $\mathrm{EtOH}$ was refluxed with stirring for $90 \mathrm{~min}$. The reaction mixture was then cooled and neutralized by sodium bicarbonate solution. The product separated was filtered, dried and recrystallized in ethanol to afford pure 1. Yield: $75 \%$; $\operatorname{mp} 285-86^{\circ} \mathrm{C} ; R_{f} 0.65$ ethyl acetate : methanol $(6: 4)$ mixture; FTIR $(\mathrm{KBr}) \mathrm{cm}^{-1}: 3441(\mathrm{NH}), 3278\left(\mathrm{NH}_{2}\right)$, $1602(\mathrm{C}=\mathrm{N}), 1074(\mathrm{C}-\mathrm{O}-\mathrm{C}) ;{ }^{1} \mathrm{H}$ NMR (DMSO- $\left.d_{6}, \delta, \mathrm{ppm}\right)$ : $12.01(\mathrm{~s}, 1 \mathrm{H}$, indole $\mathrm{NH}), 7.00-8.05(\mathrm{~m}, 4 \mathrm{H}, \mathrm{Ar}-\mathrm{H}), 5.85$ (s, $2 \mathrm{H}, \mathrm{NH}_{2}$ ), 2.82 (s, 3H, $\left.\mathrm{CH}_{3}\right) ; \mathrm{MS}(\mathrm{EI}): \mathrm{m} / z 214\left(\mathrm{M}^{+}\right)$. Anal. $\% \mathrm{C}_{11} \mathrm{H}_{10} \mathrm{~N}_{4} \mathrm{O}: \mathrm{C}, 61.67 ; \mathrm{H}, 4.71 ; \mathrm{N}, 26.15$. Found: C, 61.64; H, $4.69 ; \mathrm{N}, 26.14$.

4.2. General Procedure for the Synthesis of N-[(5-Substituted 2phenyl-1H-indol-3-yl)methylene]-5-(2-methyl-1H-indol-3-yl)1,3,4-oxadiazol-2-amines $(\mathbf{3} \boldsymbol{a}-\mathbf{3} \boldsymbol{c})$. Compound $\mathbf{1}(0.01 \mathrm{~mol})$ and 5-substituted 2-phenyl- $1 H$-indol-3-carbaldehydes (2a2c) $(0.01 \mathrm{~mol})$ were refluxed in methanol $(25 \mathrm{~mL})$ on water bath for $8 \mathrm{hrs}$. Excess of solvent was removed under reduced pressure. After cooling the reaction mixture to room temperature light yellowish crystalline product separated out was collected by filtration and recrystallized in alcohol.

$\mathrm{N}$-((5-Chloro-2-phenyl-1H-indol-3-yl)methylene)-5-(2-meth$y l-1 H$-indol-3-yl)-1,3,4-oxadiazol-2-amine (3a). Yield: 75\%, mp 228-29 ${ }^{\circ} \mathrm{C} ; R_{f} 0.77$ ethyl acetate: acetone (6:4) mixture; FTIR (KBr) cm ${ }^{-1}$ : $3310(\mathrm{NH}), 3289(\mathrm{NH}), 1626(\mathrm{C}=\mathrm{N}), 1096$ (C-O-C); ${ }^{1} \mathrm{H}$ NMR (DMSO- $d_{6}, \delta$, ppm): 12.00, 11.75 (s, 2H, indole $\mathrm{NH}$ ), 8.52 (s, $1 \mathrm{H}, \mathrm{N}=\mathrm{CH}), 6.92-7.98$ (m, 12H, Ar-H), $2.25\left(\mathrm{~s}, 3 \mathrm{H}, \mathrm{CH}_{3}\right) ;{ }^{13} \mathrm{C}-\mathrm{NMR}\left(\mathrm{DMSO}-d_{6}, 125 \mathrm{MHz}, \delta\right): 160.3$, $158.2,156.4,142.5,134.9,134.0,133.0,132.1,130.3,129.3,128.5$, $127.2,126.8,126.1,125.8,124.3,123.0,122.6,122.1,121.6,121.4$, 119.8, 119.5, 15.4; MS (EI): $m / z 451\left(\mathrm{M}^{+}\right) ; 452\left(\mathrm{M}^{+}+2\right)$. Anal. $\% \mathrm{C}_{26} \mathrm{H}_{18} \mathrm{~N}_{5} \mathrm{OCl}$ : C, 69.10; H, 4.01; N, 15.50. Found: C, 68.64; $\mathrm{H}, 3.99 ; \mathrm{N}, 15.24$.

5-(2-Methyl-1H-indol-3-yl)-N-((5-methyl-2-phenyl-1H-indol3-yl)methylene)-1,3,4-oxadiazol-2-amine (3b). Yield: 76\%, $\mathrm{mp} 240-41^{\circ} \mathrm{C} ; R_{f} 0.58$ ethyl acetate : acetone (6:4) mixture; FTIR (KBr) cm ${ }^{-1}$ : $3210(\mathrm{NH}), 3200(\mathrm{NH}), 1620(\mathrm{C}=\mathrm{N}), 1085$ (C-O-C); ${ }^{1} \mathrm{H}$ NMR (DMSO- $\left.d_{6}, \delta, \mathrm{ppm}\right): 11.93,11.52$ (s, $2 \mathrm{H}$, indole $\mathrm{NH}), 8.45$ (s, $1 \mathrm{H}, \mathrm{N}=\mathrm{CH}), 6.98-7.95$ (m, 12H, Ar-H), 3.13 (s, $3 \mathrm{H}, \mathrm{CH}_{3}$ ), 2.43 (s, $3 \mathrm{H}, \mathrm{CH}_{3}$ ); Anal. $\% \mathrm{C}_{27} \mathrm{H}_{21} \mathrm{~N}_{5} \mathrm{O}: \mathrm{C}$, 75.16; H, 4.91; N, 16.23. Found: C, 75.14; H, 4.79; N, 15.65 .

5-(2-Methyl-1H-indol-3-yl)-N-[(2-phenyl-1H-indol-3-yl)methylene]-1,3,4-oxadiazol-2-amine (3c). Yield: $78 \%, \operatorname{mp} 212-13^{\circ} \mathrm{C}$; $R_{f} 0.68$ ethyl acetate: acetone (6:4) mixture; FTIR (KBr) $\mathrm{cm}^{-1}$ : $3287(\mathrm{NH}), 3215(\mathrm{NH}), 1609(\mathrm{C}=\mathrm{N}), 1086(\mathrm{C}-\mathrm{O}-\mathrm{C}) ;{ }^{1} \mathrm{H}$ NMR (DMSO- $\left.d_{6}, \delta, \mathrm{ppm}\right): 12.10,11.92(\mathrm{~s}, 2 \mathrm{H}$, indole $\mathrm{NH}$ ), 8.61 (s, 1H, N=CH), 6.90-7.99 (m, 13H, Ar-H), 2.37 (s, 3H, $\mathrm{CH}_{3}$ ); Anal. \% $\mathrm{C}_{26} \mathrm{H}_{19} \mathrm{~N}_{5} \mathrm{O}$ : C, 74.80; $\mathrm{H}, 4.59 ; \mathrm{N}, 16.78$. Found C, 74.76; H, 4.62; N, 15.76 . 
4.3. General Procedure for the Synthesis of 2-(5-Substituted 2-phenyl-1H-indol-3-yl)-3-[5-(2-methyl-1H-indol-3-yl)-1,3,4oxadiazol-2-yl]thiazolidin-4-ones $(\mathbf{4 a - 4 c})$. To the solution of compounds $3 \mathbf{a}, \mathbf{3 b}$, and $\mathbf{3} \mathbf{c}(0.02 \mathrm{~mol})$ in DMF $(45 \mathrm{~mL})$, thioglycolic acid $(0.02 \mathrm{~mol})$ and anhydrous zinc chloride $(0.02 \mathrm{~mol})$ were added and refluxed for $6 \mathrm{hrs}$. After the completion of reaction, excess of solvent was removed under reduced pressure, cooled to room temperature, and poured onto crushed ice. The solid product thus separated was filtered, washed with cold water, and recrystallized in alcohol to afford $(4 a-4 c)$.

2-(5-Chloro-2-phenyl-1H-indol-3-yl)-3-(5-(2-methyl-1H-indol-3-yl)-1,3,4-oxadiazol-2-yl)thiazolidin-4-one (4a). Yield: $72 \%, \mathrm{mp} 272-73^{\circ} \mathrm{C} ; R_{f} 0.57$ ethyl acetate:benzene $(8: 2)$ mixture; FTIR (KBr) cm $\mathrm{cm}^{-1}: 3344(\mathrm{NH}), 3302(\mathrm{NH}), 1715$ $(\mathrm{C}=\mathrm{O}), 1627(\mathrm{C}=\mathrm{N}), 1097$ (C-O-C); ${ }^{1} \mathrm{H}$ NMR (DMSO$\left.d_{6}, \delta, \mathrm{ppm}\right): 12.12,11.79(\mathrm{~s}, 2 \mathrm{H}$, indole $\mathrm{NH}), 8.72(\mathrm{~s}, 1 \mathrm{H}$, CHCO), 6.91-8.05 (m, 12H, Ar-H), 4.81 (s, 2H, N-CH), 2.43 $\left(\mathrm{s}, 3 \mathrm{H}, \mathrm{CH}_{3}\right) ;{ }^{13} \mathrm{C}-\mathrm{NMR}$ (DMSO- $d_{6}, 125 \mathrm{MHz}, \delta$ ): 168.5, $159.2,154.5,143.9,135.0,134.1,133.0,132.8,131.1,130.1,127.8$, $127.6,126.8,126.3,125.4,125.1,123.0,122.8,122.0,121.8,120.0$, 119.0, 55.9, 35.2, 15.5; MS (EI): $m / z 525\left(\mathrm{M}^{+}\right) ; 527\left(\mathrm{M}^{+}+2\right)$. $\mathrm{C}_{28} \mathrm{H}_{20} \mathrm{~N}_{5} \mathrm{O}_{2}$ SCl: C, 63.93; H, 3.83; N, 13.31. Found: C, 63.90; $\mathrm{H}, 3.79$; N, 13.30 .

3-[5-(2-Methyl-1H-indol-3-yl)-1,3,4-oxadiazol-2-yl]-2-(5methyl-2-phenyl-1H-indol-3-yl)thiazolidin-4-one (4b). Yield: 67\%, mp $243-44^{\circ} \mathrm{C} ; R_{f} 0.53$ ethyl acetate: ethanol $(8: 2)$ mixture; FTIR (KBr) cm $\mathrm{cm}^{-1}: 3230(\mathrm{NH}), 3205(\mathrm{NH}), 1743$ $(\mathrm{C}=\mathrm{O}), 1637(\mathrm{C}=\mathrm{N}), 1086$ (C-O-C); ${ }^{1} \mathrm{H}$ NMR (DMSO- $d_{6}, \delta$, ppm): 12.03, 11.67 (s, 2H, indole $\mathrm{NH}), 8.59$ (s, $1 \mathrm{H}, \mathrm{CHCO})$, 6.96-8.25 (m, 12H, Ar-H), 4.76 (s, 2H, N-CH), 3.05 (s, 3H, $\mathrm{CH}_{3}$ ), 2.40 (s, $3 \mathrm{H}, \mathrm{CH}_{3}$ ); Anal. $\% \mathrm{C}_{29} \mathrm{H}_{23} \mathrm{~N}_{5} \mathrm{O}_{2} \mathrm{~S}: \mathrm{C}, 68.89 ; \mathrm{H}$, 4.59 ; N, 13.85. Found: C, 68.90; H, 4.60; N, 13.79 .

3-[5-(2-Methyl-1H-indol-3-yl)-1,3,4-oxadiazol-2-yl]-2-(2-phen$y l$-1H-indol-3-yl)thiazolidin-4-one (4c). Yield: 68\%, mp $250-51^{\circ} \mathrm{C} ; R_{f} 0.68$ ethyl acetate : ethanol $(8: 2)$ mixture; FTIR $(\mathrm{KBr}) \mathrm{cm}^{-1}$ : 3330, $3298(\mathrm{~N}-\mathrm{H}) ; 1715(\mathrm{C}=\mathrm{O}) ; 1627(\mathrm{C}=\mathrm{N}) ; 1097$ $(\mathrm{C}-\mathrm{O}-\mathrm{C}) ;{ }^{1} \mathrm{H}$ NMR (DMSO- $\left.d_{6}, \delta, \mathrm{ppm}\right) 12.00,11.69$ (s, $2 \mathrm{H}$, indole $\mathrm{NH}$ ); 8.68 (s, 1H, CHCO), 6.81-8.00 (m, 13H, Ar-H); 4.31 (s, $2 \mathrm{H}, \mathrm{N}-\mathrm{CH}) ; 2.62$ (s, $3 \mathrm{H}, \mathrm{CH}_{3}$ ); Anal. \% $\mathrm{C}_{28} \mathrm{H}_{21} \mathrm{~N}_{5} \mathrm{O}_{2} \mathrm{~S}$ : C, 68.41; H, 4.31; N, 14.25. Found: C, 68.35; H, 4.31; N, 14.24.

4.4. General Procedure for the Synthesis of 4-(5-Substituted 2-phenyl-1H-indol-3-yl)-1-[5-(2-methyl-1H-indol-3-yl)-1,3,4oxadiazol-2-yl]-3-phenylazetidin-2-ones $(\mathbf{5 a}-5 \boldsymbol{c})$. To Schiff's base $(\mathbf{3 a}-\mathbf{3 c})(0.02 \mathrm{~mol})$ in dry benzene $(30 \mathrm{~mL})$ containing few drops of triethyl amine, phenyl acetyl chloride $(0.02 \mathrm{~mol})$ was added with stirring during 10 mins at room temperature. After the addition was over, reaction mixture was refluxed for $1 \mathrm{hr}$. Triethyl amine hydrochloride formed was filtered off and washed several times with dry benzene. The filtrate and washings were combined and concentrated under reduced pressure. After cooling at room temperature the product obtained was filtered, washed with petroleum ether $(40: 60)$ and recrystallized in aqueous ethanol.

4-(5-Chloro-2-phenyl-1H-indol-3-yl)-1-[5-(2-methyl-1Hindol-3-yl]-1,3,4-oxadiazol-2-yl)-3-phenylazetidin-2-one (5a). Yield: $71 \%$, mp $158-59^{\circ} \mathrm{C} ; R_{f} 0.59$ ethyl acetate : acetone $(6: 4)$ mixture; FTIR (KBr) cm cm $^{-1} 343(\mathrm{NH}), 3387(\mathrm{NH}), 1765$ $(\mathrm{C}=\mathrm{O}), 1626(\mathrm{C}=\mathrm{N}), 1084$ (C-O-C); ${ }^{1} \mathrm{H}$ NMR (DMSO- $d_{6}, \delta$, ppm): 11.93, 11.58 (s, 2H, indole $\mathrm{NH}), 8.43$ (d, $1 \mathrm{H}, \mathrm{CH}-\mathrm{N})$, 7.00-8.06 (m, 17H, Ar-H), 5.58 (d, 1H, CH-Ph), 2.21 (s, $\left.3 \mathrm{H}, \mathrm{CH}_{3}\right): \mathrm{MS}(\mathrm{EI}): \mathrm{m} / z 569\left(\mathrm{M}^{+}\right) ; 571\left(\mathrm{M}^{+}+2\right)$. Anal. $\%$ $\mathrm{C}_{34} \mathrm{H}_{24} \mathrm{~N}_{5} \mathrm{O}_{2} \mathrm{Cl}$ : C, 71.64; H, 4.24; N, 12.29. Found: C, 71.60; $\mathrm{H}, 4.21 ; \mathrm{N}, 12.16$.

1-[5-(2-Methyl-1H-indol-3-yl)-1,3,4-oxadiazol-2-yl)-4-(5methyl-2-phenyl-1H-indol-3-yl]-3-phenylazetidin-2-one (5b). Yield: $64 \%, \mathrm{mp} 155-56^{\circ} \mathrm{C} ; R_{f} 0.67$ ethyl acetate: acetone (6:4) mixture; FTIR $(\mathrm{KBr}) \mathrm{cm}^{-1}: 3341(\mathrm{NH}), 3307(\mathrm{NH})$, $1743(\mathrm{C}=\mathrm{O}), 1620(\mathrm{C}=\mathrm{N}), 1093$ (C-O-C); ${ }^{1} \mathrm{H}$ NMR (DMSO$\left.d_{6}, \delta, \mathrm{ppm}\right): 12.05,11.85(\mathrm{~s}, 2 \mathrm{H}$, indole $\mathrm{NH}), 8.23(\mathrm{~d}, 1 \mathrm{H}$, CH-N), 7.09-8.00 (m, 17H, Ar-H), 4.57 (d, 1H, CH-Ph), 2.65 (s, $3 \mathrm{H}, \mathrm{CH}_{3}$ ), 2.43 (s, $3 \mathrm{H}, \mathrm{CH}_{3}$ ); Anal. \% $\mathrm{C}_{35} \mathrm{H}_{27} \mathrm{~N}_{5} \mathrm{O}_{2}$ : C, 76.48; H, 4.95; N, 12.74. Found: C, 76.37; H, 4.83; N, 12.66 .

1-[5-(2-Methyl-1H-indol-3-yl)-1,3,4-oxadiazol-2-yl)-3-phenyl4-(2-phenyl-1H-indol-3-yl)azetidin-2-one (5c). Yield: 70\%, $\mathrm{mp} 159-60^{\circ} \mathrm{C} ; R_{f} 0.76$ ethyl acetate: acetone (6:4) mixture; FTIR (KBr) cm ${ }^{-1}$ : $3200(\mathrm{NH}), 3158(\mathrm{NH}), 1712$ (C=O), 1616 $(\mathrm{C}=\mathrm{N}), 1093$ (C-O-C); ${ }^{1} \mathrm{H}$ NMR (DMSO- $d_{6}, \delta$, ppm): 11.99, 11.56 (s, 2H, indole $\mathrm{NH}), 8.13(\mathrm{~d}, 1 \mathrm{H}, \mathrm{CH}-\mathrm{N}), 6.92-7.96(\mathrm{~m}$, 17H, Ar-H), 5.00 (d, 1H, CH-Ph), 2.31 (s, 3H, $\mathrm{CH}_{3}$ ); Anal. \% $\mathrm{C}_{33} \mathrm{H}_{24} \mathrm{~N}_{5} \mathrm{O}_{2}$ : C, 75.85; $\mathrm{H}, 4.63 ; \mathrm{N}, 13.40$. Found: $\mathrm{C}, 75.74 ; \mathrm{H}$, $4.57 ; \mathrm{N}, 13.48$.

4.5. General Procedure for the Synthesis of 3-Chloro-4-(5substituted 2-phenyl-1H-indol-3-yl)-1-[5-(2-methyl-1H-indol3-yl)-1,3,4-oxadiazol-2-yl]azetidin-2-ones (5d-5f). To the solution of compounds $(3 \mathbf{a}-3 \mathbf{c})(0.02 \mathrm{~mol})$ in dioxane, chloroacetyl chloride $(0.04 \mathrm{~mol})$ and triethyl amine $(0.04 \mathrm{~mol})$ were added with constant stirring at $0-5^{\circ} \mathrm{C}$ temperature during 10 mins. After the addition was over, the reaction mixtures were refluxed for $8-10$ hrs and the excess of solvent was removed under reduced pressure. After cooling at room temperature the product obtained was filtered, washed with dioxane, dried, and recrystallized in alcohol to get pure (5d-5f).

3-Chloro-4-(5-chloro-2-phenyl-1H-indol-3-yl)-1-(5-(2-methyl$1 \mathrm{H}$-indol-3-yl)-1,3,4-oxadiazol-2-yl)azetidin-2-one (5d). Yield: $74 \%, \mathrm{mp} 273-74^{\circ} \mathrm{C} ; R_{f} 0.71$ ethyl acetate:benzene $(6: 4)$ mixture; FTIR $(\mathrm{KBr}) \mathrm{cm}^{-1}: 3411(\mathrm{NH}), 3357(\mathrm{NH}), 1716$ $(\mathrm{C}=\mathrm{O}), 1628(\mathrm{C}=\mathrm{N}), 1073(\mathrm{C}-\mathrm{O}-\mathrm{C}) ;{ }^{1} \mathrm{H}$ NMR (DMSO- $d_{6}, \delta$, ppm): 12.02, 11.89 (s, 2H, indole $\mathrm{NH}), 8.75$ (d, $1 \mathrm{H}, \mathrm{CHCO})$, 7.07-8.06 (m, 12H, Ar-H), 5.31 (d, 1H, N-CH), 2.23 (s, 3H, $\left.\mathrm{CH}_{3}\right) ;{ }^{13} \mathrm{C}-\mathrm{NMR}$ (DMSO- $d_{6}, 125 \mathrm{MHz}, \delta$ ): 167.2, 159.3, 156.4, 
$144.6,134.8,133.9,133.2,131.5,131.3,130.2,129.9,129.8,129.4$, $128.1,127.5,127.0,126.8,125.9,125.1,123.9,123.4,122.3,122.0$, 121.5, 120.1, 120.0 64.5, 63.1, 15.9; MS (EI): $m / z 527\left(\mathrm{M}^{+}\right) ; 529$ $\left(\mathrm{M}^{+}+2\right): 531\left(\mathrm{M}^{+}+4\right)$. Anal. \% $\mathrm{C}_{28} \mathrm{H}_{19} \mathrm{~N}_{5} \mathrm{O}_{2} \mathrm{Cl}_{2}$ : C, 63.65; $\mathrm{H}$, 3.62; N, 13.25. Found: C, 63.68; H, 3.55; N, 13.12 .

3-Chloro-1-(5-(2-methyl-1H-indol-3-yl)-1,3,4-oxadiazol-2-yl)4-(5-methyl-2-phenyl-1H-indol-3-yl)azetidin-2-one (5e). Yield: $69 \%, \mathrm{mp} 255-56^{\circ} \mathrm{C} ; R_{f} 0.58$ ethyl acetate:benzene $(6: 4)$ mixture; FTIR $(\mathrm{KBr}) \mathrm{cm}^{-1}: 3371,3312(\mathrm{~N}-\mathrm{H}) ; 1719$ $(\mathrm{C}=\mathrm{O}) ; 1620(\mathrm{C}=\mathrm{N}) ; 1087(\mathrm{C}-\mathrm{O}-\mathrm{C}) ;{ }^{1} \mathrm{H}$ NMR $\left(\mathrm{DMSO}-d_{6}, \delta\right.$, ppm) 11.95, 11.64 (s, 2H, indole $\mathrm{NH}) ; 8.67$ (d, 1H, CHCO); 6.97-8.16 (m, 12H, Ar-H); 4.34 (d, 1H, N-CH); 2.43 (s, 3H, $\mathrm{CH}_{3}$ ); 2.13 (s, 3H, $\mathrm{CH}_{3}$ ); Anal. \%: $\mathrm{C}_{29} \mathrm{H}_{22} \mathrm{~N}_{5} \mathrm{O}_{2} \mathrm{Cl}$ : C, 68.57; H, 4.37; N, 13.79. Found: C, 68.50; H, 4.29; N, 13.84 .

3-Chloro-1-[5-(2-methyl-1H-indol-3-yl)-1,3,4-oxadiazol-2-yl]4-(2-phenyl-1H-indol-3-yl)azetidin-2-one (5f). Yield: 72\%, $\mathrm{mp} 233-34^{\circ} \mathrm{C} ; R_{f} 0.66$ ethyl acetate : benzene (6:4) mixture; FTIR (KBr) cm ${ }^{-1}$ : $3278(\mathrm{NH}), 3200(\mathrm{NH}), 1723(\mathrm{C}=\mathrm{O}), 1618$ $(\mathrm{C}=\mathrm{N}), 1093$ (C-O-C); ${ }^{1} \mathrm{H}$ NMR (DMSO-d $\left.{ }_{6}, \delta, \mathrm{ppm}\right): 12.05$, 11.68 (s, 2H, indole $\mathrm{NH}), 8.47$ (d, $1 \mathrm{H}, \mathrm{CHCO}), 7.08-8.23(\mathrm{~m}$, 13H, Ar-H), 4.04 (d, 1H, N-CH), 2.13 (s, 3H, $\mathrm{CH}_{3}$ ); Anal. \% $\mathrm{C}_{28} \mathrm{H}_{20} \mathrm{ClN}_{5} \mathrm{O}_{2}$ : C, 68.08; H, 4.08; N, 14.18. Found: C, 68.06; $\mathrm{H}, 4.03$;, 14.11 .

\section{Biological Activities}

5.1. Antimicrobial Activities. The in vitro biological screening of the synthesized compounds (1 and 3-5) was carried out against bacterial species, E. coli, B. subtilis, and K. pneumonia and fungal species $A$. niger, $A$. flavus, and $A$. fumigates by cupplate method [28] using nutrient agar and PDA medium for antibacterial and antifungal activity, respectively. The holes of $6 \mathrm{~mm}$ diameter were punched carefully using a sterile cork borer and these were filled with test solution $(1 \mathrm{mg} / \mathrm{mL}$ in DMF), standard solution ( $1 \mathrm{mg} / \mathrm{mL}$ in $\mathrm{DMF})$, and $\mathrm{DMF}$ as control. The plates were incubated at $37^{\circ} \mathrm{C}$ for $24 \mathrm{hrs}$ and $72 \mathrm{hrs}$ for the evaluation of antibacterial and antifungal activities, respectively. The diameter of the inhibition zones for all the test compounds was measured (in $\mathrm{mm}$ ) and the results were compared with the results obtained by using streptomycin and fluconazole as positive standard for antibacterial and antifungal activities, respectively.

\subsection{Antioxidant Activity Assay}

5.2.1. 1,1-Diphenyl-2-picryl Hydrazyl (DPPH) Radical Scavenging Activity (RSA). The radical scavenging activity (RSA) of test compounds (1 and 3-5) in methanol at different concentrations $(25,50,75,100 \mu \mathrm{g} / \mathrm{mL})$ containing freshly prepared DPPH in methanol $(0.004 \% \mathrm{w} / \mathrm{v})$ was carried out and the results were compared with the results obtained by using standards (BHA, TBHQ, and AA) by Hatano's method [26]. All analyses were performed in three replicates and results were reported as averaged of three replicates. The results in percentage are expressed as the ratio of absorbance of DPPH solutions measured at $517 \mathrm{~nm}$ in the presence and the absence of test compounds by using ELICO SL171 mini spec spectrometer. The results are shown in Figures 1 and 2. The percentages of DPPH free radical scavenging activity of the samples were determined using the following equation:

$$
\% \mathrm{DPPH} \text { radical scavenging }=\frac{A_{c}-A_{s}}{A_{c}} \times 100 \text {, }
$$

where $A_{c}=$ absorbance of control; $A_{s}=$ absorbance of test sample.

5.2.2. Ferric Ions $\left(\mathrm{Fe}^{3+}\right)$ Reducing Antioxidant Power (FRAP). The reducing power of the synthesized compounds ( 1 and 3-5) was determined according to the Oyaizu method [28]. Different concentrations of samples (25, 50, 75, and $100 \mu \mathrm{g} / \mathrm{mL})$ in DMSO $(1 \mathrm{~mL})$ were mixed with phosphate buffer $(2.5 \mathrm{~mL}, 0.2 \mathrm{M}, \mathrm{pH} 6.6)$ and potassium ferricyanide $(2.5 \mathrm{~mL}, 1 \mathrm{w} / \mathrm{v})$. The mixture was incubated at $50^{\circ} \mathrm{C}$ for $20 \mathrm{~min}$. A portion of trichloroacetic acid $(2.5 \mathrm{~mL}, 10 \% \mathrm{w} / \mathrm{v})$ was then added to the mixture and the mixture was centrifuged for $10 \mathrm{~min}$ at $1000 \times \mathrm{g}$. The upper layer of solution $(2.5 \mathrm{~mL})$ was mixed with distilled water $(2.5 \mathrm{~mL})$ and ferric chloride $(0.5 \mathrm{~mL}, 0.1 \mathrm{w} / \mathrm{v})$. Absorbance at $700 \mathrm{~nm}$ was then measured in spectrophotometer. Higher absorbance of the reaction mixture indicated greater reducing power. The results are shown in Figures 3 and 4.

5.2.3. Ferrous Ions $\left(\mathrm{Fe}^{2+}\right)$ Metal Chelating Activity. The ferrous ion chelating activities of synthesized compounds (1 and 3-4) and standards were estimated using the method reported by Dinis and colleagues [29]. The test samples (25, $50,75$, and $100 \mu \mathrm{g} / \mathrm{mL})$ in ethanol $(0.4 \mathrm{~mL})$ were added to ferrous chloride $(0.05 \mathrm{~mL}, 2 \mathrm{mM})$ prepared in ethanol. The reaction was initiated by the addition of ferrozine $(0.2 \mathrm{~mL}$, $5 \mathrm{mM}$ ) and the volume was adjusted to $3.5 \mathrm{~mL}$ with ethanol and $0.5 \mathrm{~mL}$ water so as to make the final total volume $4.0 \mathrm{~mL}$. Ferrozine reacts with the divalent iron to forms stable magenta complex species that were very soluble in water. The mixture was shaken vigorously and kept at room temperature for $10 \mathrm{~min}$. Then the absorbance of the solution was measured spectrophotometrically at $562 \mathrm{~nm}$. All analyses were run in three triplicates and results are reported as the averages of three replicates. The results are shown in Figures 5 and 6 . The percent inhibition of the ferrozine- $\mathrm{Fe}^{2+}$ complex formation was calculated using the following formula:

$$
\% \text { Ferrous ion chelating effect }=\frac{A_{c}-A_{s}}{A_{c}} \times 100,
$$

where $A_{c}=$ absorbance of control; $A_{s}=$ absorbance of test sample.

\section{Conflict of Interests}

Since the authors have procured the IR, NMR, and mass spectra of the synthesized compounds from the National Research Centre, namely, The Indian Institute of Technology, Madras, Chennai, India, as per the condition of institution authors should acknowledge their services in the research paper while 
publishing the work, which includes the data provided by them in the research paper. The same has been acknowledged in the acknowledgement section. The authors do not have any agreement, financial assistance, or sponsorship from PerkinElmer spectrum, Brucker NMR,..., and so forth. These names are mentioned in the experimental protocol as these are the instrument models, and it is mandatory for authors to mention the instrument models used to scan the spectra of unknown compounds. Otherwise the corresponding author or coauthors have no direct financial relationship with the commercial identity mentioned in our paper in any form.

\section{Acknowledgments}

The authors are thankful to the Chairman, Department of Chemistry, Gulbarga University, Gulbarga, for providing laboratory facilities, to the Chairman, Department of Microbiology, Gulbarga University, Gulbarga, for providing facilities to carry out antimicrobial activity tests, and to the Director, Indian Institute of Technology, Madras, Chennai, for providing spectral data, presented at the "100th Indian Science Congress" organized by the Indian Science Congress Association, Kolkata, during January 3rd-7th, 2013.

\section{References}

[1] S. Harper, B. Pacini, S. Avolio et al., "Development and preliminary optimization of indole- $\mathrm{N}$-acetamide inhibitors of hepatitis $\mathrm{C}$ virus NS5B polymerase," Journal of Medicinal Chemistry, vol. 48, no. 5, pp. 1314-1317, 2005.

[2] G. N. Anilkumar, C. A. Lesburg, O. Selyutin et al., "I. Novel HCV NS5B polymerase inhibitors: Discovery of indole 2carboxylic acids with C3-heterocycles," Bioorganic and Medicinal Chemistry Letters, vol. 21, no. 18, pp. 5336-5341, 2011.

[3] G. N. Anilkumar, C. A. Lesburg, O. Selyutin et al., "II Novel HVC NS5B polymerase inhibitors: discovovery of indole C2 acyl sulfuonamides," Bioorganic \& Medicinal Chemistry Letters, vol. 22, pp. 713-717, 2012.

[4] J. F. Dropinski, T. Akiyama, M. Einstein et al., "Synthesis and biological activities of novel aryl indole-2-carboxylic acid analogs as PPAR $\gamma$ partial agonists," Bioorganic and Medicinal Chemistry Letters, vol. 15, no. 22, pp. 5035-5038, 2005.

[5] R. Akue-Gedu, E. Debiton, Y. Ferandin et al., "Synthesis and biological activities of aminopyrimidyl-indoles structurally related to meridianins," Bioorganic and Medicinal Chemistry, vol. 17, no. 13, pp. 4420-4424, 2009.

[6] M.-J. R. P. Queiroz, A. S. Abreu, M. S. D. Carvalho, P. M. T. Ferreira, N. Nazareth, and M. São-José Nascimento, "Synthesis of new heteroaryl and heteroannulated indoles from dehydrophenylalanines: antitumor evaluation," Bioorganic and Medicinal Chemistry, vol. 16, no. 10, pp. 5584-5589, 2008.

[7] C.-K. Ryu, J. H. Yoon, A. L. Song, H. A. Im, J. Y. Kim, and A. Kim, "Synthesis and antifungal evaluation of pyrido[1,2a]indole-1,4-diones and benzo[f]pyrido[1,2-a]indole-6,11diones," Bioorganic and Medicinal Chemistry Letters, vol. 22, no. 1, pp. 497-499, 2012.

[8] D. S. Mehta, K. H. Sikotra, and V. H. Shah, "Synthesis and biological screening of some new novel indole derivatives," Indian Journal of Chemistry B, vol. 44, no. 12, pp. 2594-2597, 2005.
[9] A. Scribner, J. A. Moore III, G. Ouvry et al., "Synthesis and biological activity of anticoccidial agents: 2,3-diarylindoles," Bioorganic and Medicinal Chemistry Letters, vol. 19, no. 5, pp. 1517-1521, 2009.

[10] A. Zarghi, S. A. Tabatabai, M. Faizi et al., "Synthesis and anticonvulsant activity of new 2-substituted-5-(2-benzyloxyphenyl)-1,3,4-oxadiazoles," Bioorganic and Medicinal Chemistry Letters, vol. 15, no. 7, pp. 1863-1865, 2005.

[11] A. N. Krasovskii, A. K. Bulgakov, A. P. Andrushko et al., "Antimicrobial and tuberculostatic activity of 5-aryl(hetaryl)1,3,4-oxadiazole-2-thiones and their derivatives," Pharmaceutical Chemistry Journal, vol. 34, no. 3, pp. 115-117, 2000.

[12] S. V. Bhandari, K. G. Bothara, M. K. Raut, A. A. Patil, A. P. Sarkate, and V. J. Mokale, "Design, synthesis and evaluation of antiinflammatory, analgesic and ulcerogenicity studies of novel s-substituted phenacyl-1,3,4-oxadiazole-2-thiol and schiff bases of diclofenac acid as nonulcerogenic derivatives," Bioorganic and Medicinal Chemistry, vol. 16, no. 4, pp. 1822-1831, 2008.

[13] B. S. Sudha, S. Shashikanth, S. A. Khanum, and S. N. Sriharsha, "Synthesis and pharmacological screening of 5-(4aroyl)-aryloxy methyl-2-thio-1,3,4-oxadiazole," Indian Journal of Pharmaceutical Sciences, vol. 65, no. 5, pp. 465-470, 2003.

[14] K. M. Lokanatha Rai and N. Linganna, "Synthesis and evaluation of antimitotic activity of alkylated 2-amino- 1,3,4oxadiazole derivatives," Farmaco, vol. 55, no. 5, pp. 389-392, 2000.

[15] S. Saxena, M. Verma, A. K. Saxena, and K. Shanker, "1,3,4oxadiazole thiones as inflammation inhibitors," Indian Journal of Pharmaceutical Sciences, vol. 54, no. 1, pp. 1-3, 1992.

[16] M. Zareef, R. Iqbal, N. A. Al-Masoudi, J. H. Zaidi, M. Arfan, and S. A. Shahzad, "Synthesis, anti-HIV, and antifungal activity of new benzensulfonamides bearing the 2,5-disubstituted-1,3,4oxadiazole moiety," Phosphorus, Sulfur and Silicon and the Related Elements, vol. 182, no. 2, pp. 281-298, 2007.

[17] E. Meyer, A. C. Joussef, and L. D. B. P. De Souza, "Synthesis of new 1,2,4- and 1,3,4-oxadiazole derivatives as potential nonpeptide angiotensin II receptor antagonists," Synthetic Communications, vol. 36, no. 6, pp. 729-741, 2006.

[18] K. M. Khan, S. A. Shahzadi, M. Ranil et al., "Structure-activity relationship of tyrosinase inhibitory combinatorial library of 2,5- disubstituted-1,3,4-oxadiazole," Letters in Organic Chemistry, pp. 3286-3288, 2006.

[19] M. Shaban, A. E. Nasar, and S. M. EL-Badary, "Synthesis of some 1,3,4-oxadiazole and bis 1,3,4-oxadiazole that possess nematicidal insecticidal and herbicidal activity," Journal of Islamic Academy of Sciences, vol. 4, no. 3, pp. 184-191, 1991.

[20] A.-R. A. H. Farghaly, "Synthesis, reactions and antimicrobial activity of some new indolyl-1,3,4-oxadiazole, triazole and pyrazole derivatives," Journal of the Chinese Chemical Society, vol. 51, no. 1, pp. 147-156, 2004.

[21] B. Narayana, B. V. Ashalatha, K. K. Vijaya Raj, and B. K. Sarojini, "Synthesis and studies on antimicrobial, antiinflammatory and antiproliferative activities of heterocycles derived from 4-/5-/6-/7-nitro/5fluoro/chloro/bromoindole-2carbohydrazides," Indian Journal of Chemistry B, vol. 48, no. 12, pp. 1794-1805, 2009.

[22] M. Bhalla, V. K. Srivastava, T. N. Bhalla, and K. Shanker, "Antiinflammatory and analgesic activity of indolyl quinazolones and their congeners," Arzneimittel-Forschung/Drug Research, vol. 43, no. 5, pp. 595-600, 1993.

[23] P. B. R. Kumar, S. Subramaniyan, K. Yamini, and R. Suthakaran, "Synthesis of some novel $1-\mathrm{H}$ pyrazole derivatives and their 
antibacterial activity studies," Rasayan Journal of Chemistry, vol. 4, no. 2, pp. 400-404, 2011.

[24] S. P. Hiremath, J. S. Biradar, and M. G. Purohit, "A new route to indolo [3, 2-b]isoquinolines," Indian Journal of Chemistry B, vol. 21, pp. 249-253, 1982.

[25] Indian Pharmacopeia, Appendix 4, Government of India, New Delhi, India, 3rd edition, 1985.

[26] T. Hatano, H. Kagawa, T. Yasuhara, and T. Okuda, "Two new flavonoids and other constituents in licorice root: their relative astringency and radical scavenging effects," Chemical and Pharmaceutical Bulletin, vol. 36, no. 6, pp. 2090-2097, 1988.

[27] M. Strlič, T. Radovič, J. Kolar, and B. Pihlar, "Anti- and prooxidative properties of gallic acid in fenton-type systems," Journal of Agricultural and Food Chemistry, vol. 50, no. 22, pp. 6313-6317, 2002.

[28] M. Oyaizu, "Studies on products of the browning reaction. Antioxidative activities of browning reactionproducts prepared fromglucosamine," Japanese Journal of Nutrition, vol. 44, no. 6 , pp. 307-315, 1986.

[29] T. C. P. Dinis, V. M. C. Madeira, and L. M. Almeida, "Action of phenolic derivatives (acetaminophen, salicylate, and 5aminosalicylate) as inhibitors of membrane lipid peroxidation and as peroxyl radical scavengers," Archives of Biochemistry and Biophysics, vol. 315, no. 1, pp. 161-169, 1994. 

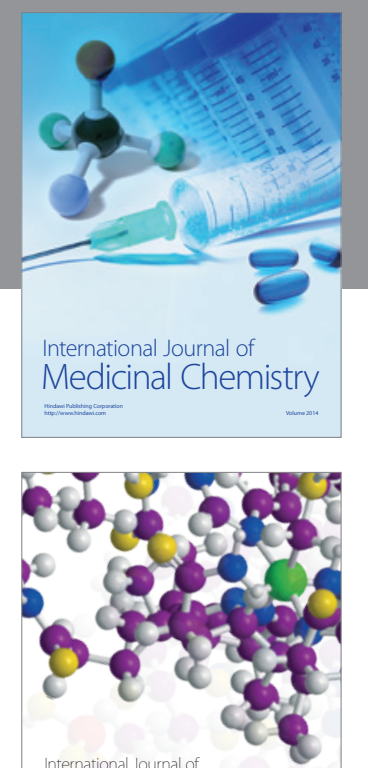

\section{Carbohydrate} Chemistry

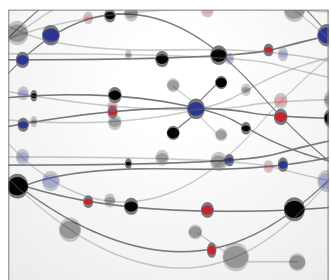

The Scientific World Journal
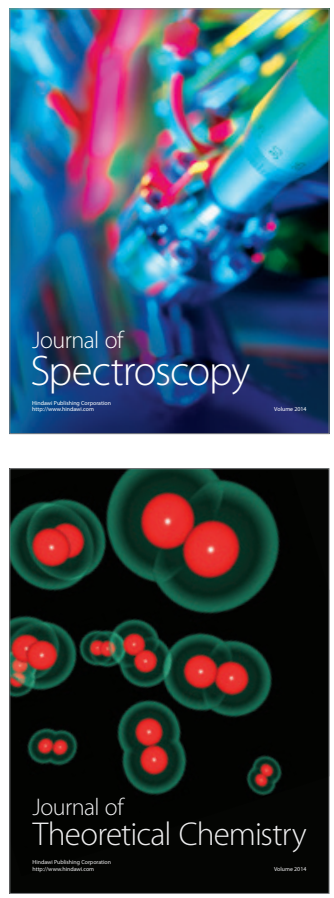
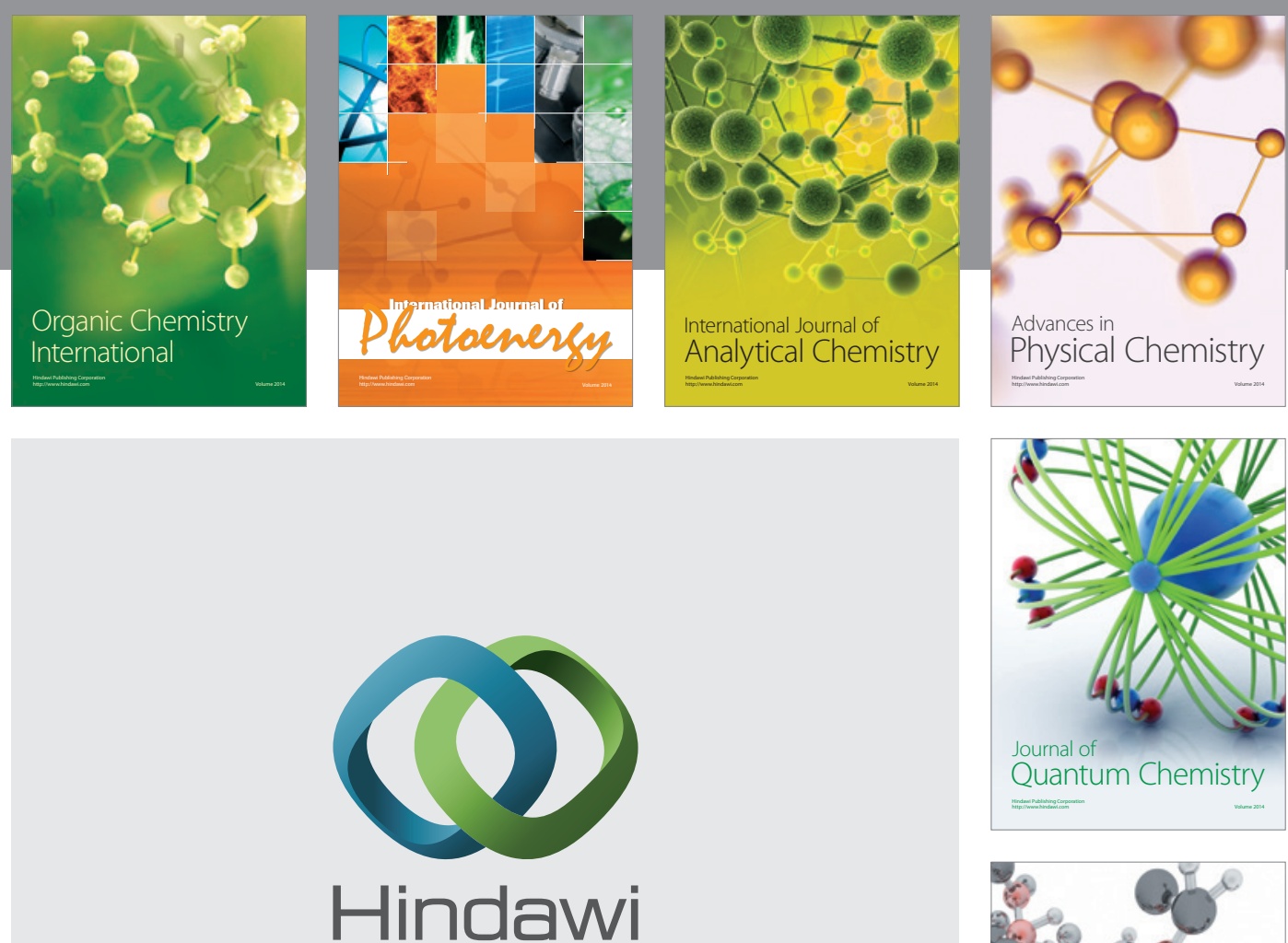

Submit your manuscripts at

http://www.hindawi.com

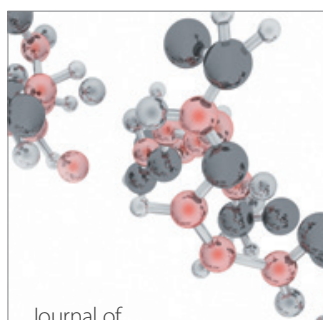

Analytical Methods

in Chemistry

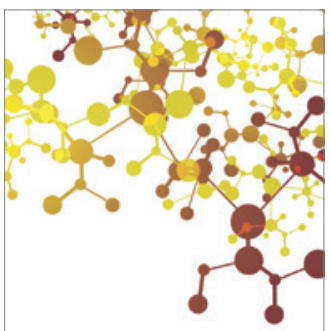

Journal of

Applied Chemistry

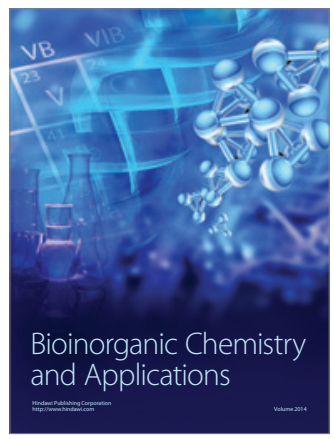

Inorganic Chemistry
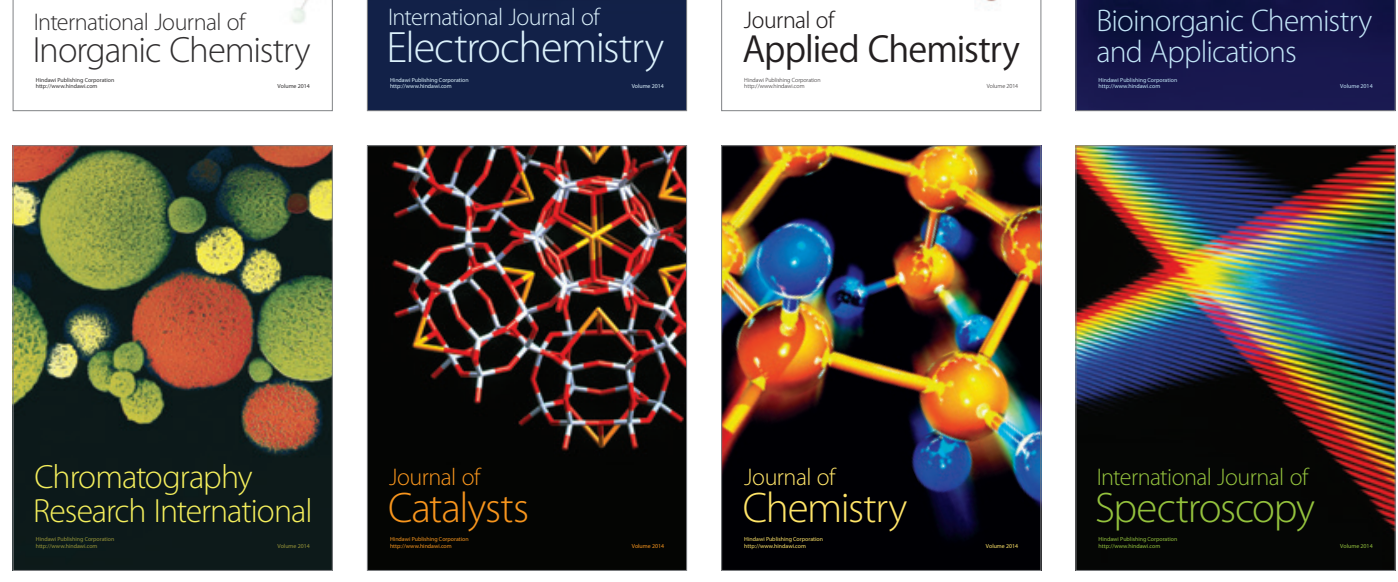